\author{
Agnieszka Kisztelińska-Węgrzyńska \\ Wydział Studiów Międzynarodowych i Politologicznych \\ Uniwersytet Łódzki \\ ORCID 0000-0003-3682-4442 \\ agnieszka.kisztelinska@uni.lodz.p1
}

\title{
Inwestycje austriackie w Polsce przed 1989 rokiem
}

\section{Wprowadzenie}

Inwestycje austriackie w Polsce były ważnym elementem powojennych dwustronnych stosunków gospodarczych. Biorąc pod uwagę dostępne materiały źródłowe i opracowania analizujące relacje gospodarcze pomiędzy II Republiką Austrii i Polską Rzeczpospolitą Ludową, zawężono okres analizy do lat 1970-1989. Przy tak przyjętych cezurach próbowano ustalić, w jakim zakresie aktywność państwa demokratycznego w obszarze działań gospodarczych przenosiła się na politykę kraju, który funkcjonował w odmiennych realiach ekonomicznych i politycznych. Wzięto przy tym pod uwagę działania państwa neutralnego - Austrii - postrzeganego przez kraje wschodnie jako potencjalnego partnera. Republika Austriacka wywierała na ten obszar widoczny wpływ w zakresie przedsiębiorczości. Wyjaśnień wymaga kwestia natężenia tego procesu, stopnia generowanych zmian i skutków w odniesieniu do Polski. Polska traktowana była przez powojenną Austrię jako inicjator przemian w regionie i partner w zakresie wymiany dóbr i surowców. Kryteria temporalne ograniczono do okresu przed 1989 rokiem, w tym czasie bowiem mechanizmy oddziaływania obydwu państw były stałe. Okres transformacji przyniósł dodatkowe zmiany w obrębie warunków funkcjonowania partnerów gospodarczych. Niniejszy artykuł ma na celu ocenę wpływu austriackich bodźców ekonomicznych, głównie inwestycji bezpośrednich, na sytuację polityczną 
Polski ${ }^{1}$. Ich skuteczność szacowana jest na podstawie konkretnych inicjatyw podejmowanych nie tylko w trosce o interes narodowy republiki, lecz także odpowiedzialność za wsparcie gospodarcze i polityczne obszaru Europy Środkowo-Wschodniej. W ocenie tej stosuje się kryterium zorientowane na cel $^{2}$. Cele zostaną określone na podstawie obserwacji konkretnych wydarzeń $i$ istotnych decyzji ${ }^{3}$. Pod uwagę zostanie wzięta pozycja państwa i jego siła oddziaływania na inne podmioty i region. Pole badawcze dotyczy następstw politycznych austriackich inicjatyw gospodarczych realizowanych na obszarze Polski. Ważnym pytaniem pozostaje zagadnienie, w jaki sposób polski rząd reagował na oferty składane przez władze austriackie. Przyjęta hipoteza dotyczy integracji w regionie. Austriacy poprzez współpracę z Polską dążyli do umocnienia pozycji gospodarczej i politycznej sąsiednich państw wschodnich ${ }^{4}$. Czynili to głównie w trosce o własne korzyści i zapewnienie ciągłości wymiany handlowej z tym obszarem.

Badania te miały na celu wyjaśnienie, na jakich zasadach działały mechanizmy podejmowania optymalnych decyzji ekonomicznych, a także kształtowania przy tej okazji świadomości na temat skutków politycznych realizacji inwestycji zagranicznych w obydwu krajach. Ważne było, czy oprócz oczywistych celów gospodarczych/biznesowych rząd austriacki, promując inwestycje w Polsce, realizował także wybrane cele polityczne. Metoda historyczna została uzupełniona analizą statystyczną i badaniem podstaw instytucjonalno-prawnych wzajemnych stosunków ${ }^{5}$.

W pracy przyjęto, że podejmowane działania miały na celu stworzenie warunków do realizacji inwestycji bezpośrednich, a także kooperacji w szerszym gronie w ramach regionu. Przyjęto, że inwestycja była rodzajem zaangażowania gospodarczego dla osiągnięcia korzyści politycznych. Trwałe zainteresowanie inwestora podmiotem zagranicznym objawia się bezpośrednimi inwestycjami (BIZ) ${ }^{6}$. Definiowane są one najczęściej jako przepływ środków finansowych i/lub rzeczowych w celu podjęcia długotrwałej działalności gospodarczej za granicą i sprawowania kontroli zarządczej przedsiębiorstwa inwestującego nad podmiotem mającym siedzibę za granicą w celu osiągnięcia zysku? . Stabilność polityczna państw sąsiednich była ważnym elementem polityki za-

P. Matera, Economic Incentives as Tools of Foreign Policy: Polish Engagement in Ukraine, „European Review”, s. 1-2. DOI: https://doi.org/10.1017/S106279872000109XPublished online by Cambridge University Press: 03 August 2020 (dostęp: 15 września 2020).

2 W.J. Long, Economic Incentives and Bilateral Cooperation, University of Michigan Press, Michigan 1996, s. 22-31.

3 D. Baldwin, Economic Statecraft, Princeton University Press, New Jersey 1985, s. 13-14.

$4 \mathrm{Na}$ temat badania roli i jej modeli zob. J. Van den Bosch, Polish Foreign Policy and the ENP. Complementing or Conflicting Interests, Catholic University Leuven, Leuven 2010, s. 43-88.

5 R. Backer, L. Czechowska, G. Gadomska et al. (red.), Metodologia badań politologicznych, Polskie Towarzystwo Nauk Politycznych, Warszawa 2016, s. 97-104.

6 Bezpośrednie inwestycje zagraniczne (BIZ) to poza zależnościami kapitałowymi przemieszczanie innych czynników produkcji (transfer wiedzy, umiejętności technicznych, menadżerskich i marketingowych). A. Budnikowski, Międzynarodowy obrót czynników produkcji, w: idem, E. Kawecka-Wyrzykowska, (red.), Międzynarodowe stosunki gospodarcze, Państwowe Wydawnictwo Ekonomiczne, Warszawa 1996, s. 127.

7 G. Ciurzyńska, Międzynarodowe przepływy kapitału, w: A. Budnikowski, E. Kawecka-Wyrzykowska (red.), Międzynarodowe stosunki gospodarcze, s. 56. 
granicznej powojennej Austrii. Polska funkcjonowała w ograniczonym środowisku ekonomicznym uzależnionym od decyzji odmiennych od wolnorynkowych ${ }^{8}$. Skutki gospodarcze centralnego planowania w Polsce opisano m.in. w pracy Bliżej centrum czy na peryferiach ${ }^{9}$. Analizując skutki austriackiej polityki inwestycyjnej można wskazać, na ile powtarzalne były działania państw zachodnich wobec krajów komunistycznych $\mathrm{w}$ odniesieniu do rozwoju regionalnych inicjatyw gospodarczych ${ }^{10}$. Następstwem inwestycji bezpośrednich były inwestycje portfelowe, które pojawiły się w Polsce w okresie transformacji ${ }^{11}$.

Wśród najważniejszych skutków BIZ dla państw goszczących badacze przedmiotu wymieniają: związek BIZ z zapełnieniem luki kapitałowej, poprawę sytuacji gospodarczej (zatrudnienia, produkcji), transfer technologii, usprawnienie organizacji produkcji, modernizacja przedsiębiorstw, rozwój naukowo-badawczy. Dodatkowo także polepszenie kwalifikacji pracowników, zwiększenie poziomu inwestycji i zatrudnienia, szczególnie tam, gdzie realizuje się inwestycje od podstaw, zwiększenie wpływów do budżetu, normalizacja sytuacji rynkowej. Pojawienie się zagranicznych konkurentów powoduje wzrost konkurencyjności, a także efekt domina, BIZ czynią kraj bardziej atrakcyjnym dla kolejnych potencjalnych inwestorów ${ }^{12}$.

Konsekwencjami BIZ mogą być także zwiększone obawy przed skutkami zdominowania gospodarki, czy poszczególnych branż, przez zagranicznych inwestorów, ograniczenie suwerenności i skuteczności własnej polityki makroekonomicznej. W regionach bogatych w surowce często pojawiają się obawy o nadmierną i sprzeczną z długookresowym interesem państwa goszczącego eksploatację zasobów surowcowych. Skutkiem negatywnym jest kupowanie przez inwestorów zagranicznych zakładów produkcyjnych

8 E. Gieroczyńska, Efektywne wykorzystanie private equity $i$ venture capital, „Biuletyn Analiz UKIE“ nr 16; http://www.ukie.gov.pl/ (dostęp: 11 września 2020).

$9 \quad$ L. Jasiński, Bliżej centrum czy na peryferiach? Polskie kontakty gospodarcze z zagranica w XX wieku, Wydawnictwo Trio, Warszawa 2011.

10 M. Uryniak, Korzyści i zagrożenia związane z bezpośrednimi inwesytcjami zagranicznymi, w: W. Karaszewski (red.), Bezpośrednie inwestycje zagraniczne w Polsce, Wydawnictwo Uniwersytetu Mikołaja Kopernika, Toruń 2003, s. 226; J. Pach, Bezpośrednie inwestycje zagraniczne w świetle bezpieczeństwa ekonomicznego na przykładzie Polski w latach dziewiędziesiatych XX wieku, Wydawnictwo Naukowe Akademii Pedagogicznej, Kraków 2001, s. 71.

11 M.A. Weresa, Skutki inwestycji zagranicznych dla gospodarki kraju przyjmujacego-Doświadczenie Polski, „Zeszyty BRE Bank-Case”, nr 62, s. 8. Inwestycje portfelowe również zaliczamy do inwestycji zagranicznych. Podstawowymi różnicami między tymi sposobami inwestowania są: osoba inwestora, forma, cel i motywy inwestycji, jak również zakres czasowy czy rodzaj aktywów wnoszonych do inwestycji. Kierowanie zagraniczną działalnością gospodarczą zasadniczo odróżnia BIZ od inwestycji portfelowych. W inwestycjach portfelowych podmiot dokonuje wywozu kapitału i inwestuje w działalność gospodarczą, jednakże nie zyskuje on odpowiedniej ilości akcji, dzięki którym może dokonywać kontroli. Głównym motywem realizacji zagranicznych inwestycji portfelowych jest zróżnicowanie portfela inwestycyjnego dla mniejszego ryzyka i osiągania zysku przez umieszczenie w zagranicznych papierach wartościowych funduszy, które oferują po przeliczeniu różnic kursów walutowych atrakcyjniejszą realną stopę procentową.

12 P. Bożyk, J. Misala, M. Puławski, Międzynarodowe stosunki ekonomiczne, Polskie Wydawnictwo Ekonomiczne, Warszawa 2002, s. 121. 
w celu ich zamknięcia, aby nie stanowiły konkurencji dla innych danej branży ${ }^{13}$. Obawy polskie odnośnie do negatywnych skutków BIZ były znaczne. Stąd nacisk na modernizację podczas planowania wspólnych przedsięwzięć. Wielokrotnie podczas rozmów dwustronnych władze austriackie domagały się włączania do dyskusji nad programem działania osób decyzyjnych. Ograniczenia w przekazywaniu ustaleń i informacji były dużym obciążeniem w trakcie negocjacji. Olbrzymie trudności generowały także brak jednolitych metod gromadzenia i opracowywania danych dotyczących przepływów międzynarodowych ${ }^{14}$. Część tych danych utajniano lub uwalniano z opóźnieniem. Poszczególne kraje stosowały odmienne definicje inwestycji, co prowadziło do rozbieżności $\mathrm{w}$ dokonywaniu porównań. Zwraca na to uwagę w swoich badaniach Janina Witkowska.

Biorąc pod uwagę skutki napływu austriackich inwestycji do Polski, można je podzielić według następujących pól oddziaływania: zasoby, przedsiębiorczość, efektywność i stosunki polityczno-ekonomiczne. W każdym z nich można wyróżnić skutki pozytywne i negatywne w kontekście warunków, jakie stworzyło państwo goszczące. Wśród najważniejszych oddziaływań pozytywnych należy wymienić: dostępność zasobów przekazywanych przez inwestorów, ich atrakcyjne ceny i plany rozwojowe wspierające konkurencyjność Polski na rynkach międzynarodowych ${ }^{15}$, politykę promującą przedsiębiorczość i przeciwdziałanie niedoskonałościom rynku, tworzenie przejrzystego porządku prawnego, efektywność polityki makroekonomicznej i planowanie działania długofalowego. Dodatkowo warto wspomnieć o rozwoju polityki informacyjnej ułatwiającej przemiany polityczne, społeczne i kulturowe głównie poprzez transfer wzorców relacji biznesowych, konsumpcyjnych i kulturowych ${ }^{16}$.

\section{Cele gospodarcze i polityczne w relacjach polsko-austriackich}

Formułowanie celów w powojennych polsko-austriackich relacjach gospodarczych ulegało nieznacznym korektom. Oceniając zmianę, warto przyjrzeć się austriackim projektom gospodarczym podejmowanym w relacjach dwustronnych przed 1989 rokiem. W tym celu należy odpowiedzieć na następujące pytania:

- Czy pomysły te były częścią szerszego planu realizowanego wobec państw wschodnich?

- Czy państwo polskie liberalizowało swoje praktyki w celu przyciągania inwestycji?

- Czy promowano atuty i korzystne warunki dla potencjalnych inwestorów?

- Czy zdobywanie nowych inwestorów wiązało się z długofalowymi celami rozwojowymi Polski?

13 M. Guzek, Międzynarodowe stosunki gospodarcze. Zarys teorii i polityki handlowej, Wydawnictwo Wyższej Szkoły Bankowej, Poznań 2001, s. 142-143.

14 J. Witkowska, Bezpośrednie inwestycje zagraniczne w warunkach stowarzyszenia i przyszłego członkostwa w WE, Państwowe Wydawnictwo Ekonomiczne, Warszawa 1993, s. 5.

15 J. Schroder, Planowanie $w$ przedsiębiorstwach handlu zagranicznego - kierunki przemian, „Handel Zagraniczny” 1987, nr 11, s.11-14.

16 United Nations Conference on Trade and Development, United Nations, New York-Geneva 1999, s. 235. 
- Czy stworzono infrastrukturę instytucji zajmujących się tworzeniem warunków do pozyskiwania zagranicznych inwestycji?

- W jakim zakresie selekcjonowano potencjalne inwestycje?

Zainteresowanie polityczne i gospodarcze Austrii krajami Europy Środkowo-Wschodniej miało zróżnicowane podłoże. Aktywizacja środowisk twórczych, a także wspólne inwestycje podnoszące poziom społeczny przeciętnych obywateli państw wschodnich, to zadania, których wsparcie interesowało Austrię przez cały okres powojenny na równi $z$ reprezentowaniem interesów Wiednia na tym obszarze ${ }^{17}$. Podejmując inicjatywy dotyczące kooperacji przemysłowej wychodzono z założenia, że stabilność gospodarcza tego obszaru sprzyjać będzie realizacji podstawowego zadania władz austriackich, jakim było łagodzenie skutków jednostronnych powiązań ekonomicznych Austrii z państwami zachodnimi, w tym zwłaszcza z RFN ${ }^{18}$. Prymarne założenie, jakie przyjęto w Wiedniu, dotyczyło zgody na podjęcie współpracy ekonomicznej tam, gdzie było to opłacalne, ale także przy poszanowaniu zasad typowych dla wolnego rynku. Biorąc pod uwagę strukturę agrarną Polski, wymieniano ją na dalszym miejscu po Czechosłowacji, Węgrzech i NRD ${ }^{19}$.

Polsko-austriackie powojenne relacje gospodarcze wpisywały się w szersze procesy dotyczące całego kontynentu. Po zakończonym cyklu koniunktury trwającym od połowy lat pięćdziesiątych do początków lat siedemdziesiątych, przeinwestowanie widoczne w krajach zachodnich, zwłaszcza w sektorach przemysłowych nowoczesnej gospodarki konsumpcyjnej, wywołało nadmiar mocy produkcyjnych. Zdaniem Van der Wee: „industrializacja bloku wschodniego dotyczyła podobnych sektorów i przygotowała grunt pod braki żywności, surowców i energii" ${ }^{20}$. Następujące zmiany pokoleniowe wymusiły wzrost płac. Pracodawcy zaś podnieśli ceny, aby zrekompensować straty z tego wynikające ${ }^{21}$. Stosunkowo łatwym rozwiązaniem było przeniesienie części produkcji do krajów wschodnich. Rozwijane tam konsekwentnie tradycyjne branże związane z przemysłem ciężkim: górnictwo, hutnictwo, metalurgia i przetwórstwo były mało wydajne. Do rozwoju nowoczesnych gałęzi produkcji brakowało energooszczędnych technologii. W roku 1980 wytworzenie jednostki produktu wymagało osiem razy więcej energii niż w krajach zachodnich ${ }^{22}$.

17 Dokument regulujący wejście w życie polityki dobrego sąsiedztwa Nachbarchaftspolitik wdrażano w okresie rządów socjalistów od 1970 roku. A. Kisztelińska-Węgrzyńska, Bruno Kreisky. Polityka zagraniczna i dyplomacja wobec PRL (1959-1983), Wydawnictwo Uniwersytetu Lódzkiego, Łódź 2018, s. 126-130.

18 E. März, Wirtschaftswunder Österreichs, w: J. Hannak (red.), Bestand aufnahmen Österreich 1945-1963, Universität Wien, Wien 1966, s. 120.

19 D. Stiefl, Österreich und die planwirtschaftlichen Länder, w: G. Enderle-Burcel (red.), Zarte Bande: Österreich und die europäischen planwirtschaftlichen Länder. Delicate Relationship, WUV-Universitätsverlag, Wien 2006, s. 16-17.

20 H. Van der Wee, Prosperity and Upheaval: The World Economy 1945-1980, University of California Press, Berkeley 1986, s. 90.

21 I.T. Berend, Od bloku sowieckiego do Unii Europejskiej. Transformacja ekonomiczna i spoteczna Europy Środkowo-Wschodniej od 1973 roku, Wydawnictwo Uniwersytetu Jagiellońskiego, Kraków 2011, s. 10.

22 I.T. Berend, Od bloku sowieckiego do Unii Europejskiej..., s. 22. 
W odniesieniu do kwestii gospodarczych Austriacy byli głównie zainteresowani rozbudową infrastruktury. Stawiano na modernizację i rozbudowę starej arterii komunikacyjnej łączącej kraje naddunajskie. Stąd wielokrotnie modyfikowane plany uzupełnienia trasy komunikacyjnej łączącej Dunaj z Renem i dalej z Morzem Północnym oraz z Odrą i Morzem Bałtyckim ${ }^{23}$. Choć większość badaczy austriackich i niemieckich podkreśla brak zainteresowania obszarem wschodnim, tzw. Oststaaten, po II wojnie światowej, to dane liczbowe dotyczące gospodarczej aktywności Austrii i Niemiec w regionie są jednoznacznie. Zaangażowanie ekonomiczne zachodnich sąsiadów na Wschodzie opisane w pracach Jerzego Kozeńskiego, Bogdana Koszela, Wandy Jarząbek i Janiny Witkowskiej wskazuje stałą rosnącą tendencję kooperacji z krajami Europy Środkowo-Wschodniej ${ }^{24}$.

Korzystając z przychylności rządów wschodnich, Austria próbowała odbudować pozycję ważnego partnera gospodarczego $\mathrm{w}$ regionie, wypracowaną jeszcze $\mathrm{w}$ okresie międzywojennym. Pierwsza Republika wysyłała na Wschód przed 1938 rokiem od 28 do $35 \%$ swojej produkcji25. Państwa Europy Środkowej postrzegały Wiedeń jako ważnego partnera gospodarczego ${ }^{26}$. Zarówno badacze austriaccy, jak i polscy podkreślają wagę sentymentów historycznych w procesie nawiązania i rozszerzania wymienionej współpracy gospodarczej ${ }^{27}$. Komentarzem dotyczącym celów realizowanej polityki sąsiedztwa była wypowiedź kanclerza Bruno Kreisky’ego: „Przyzwyczajeni jesteśmy uważać za swych sąsiadów nie tylko te kraje, z którymi łączą nas wspólne granice. W naszym mniemaniu pośrednimi naszymi sąsiadami są wszystkie państwa basenu Dunaju, a także te państwa, z którymi - jak się rzecz ma właśnie w przypadku Polski - łączą nas od stuleci ścisłe związki. W stosunku do tych państw prowadziliśmy stale politykę normalizacji, jak to nazwałem w 1959 roku, a moja wizyta w Warszawie przed piętnastu laty miała znaczenie decydujące. Ta oto właśnie polityka zapoczątkowała późniejszy rozwój zabiegów na rzecz zapewnienia odprężenia w Europie"28.

23 E. Röhrlich, Kreiskys Aussenpolitik. Zwischen österreichischer Identität und internationalen Programm, Zeitgeschichte im Kontext 2, V\&R Unipress, Göttingen 2009, s. 250.

24 J. Kozeński, Austria 1918-1968: dzieje społeczne i polityczne, Wydawnictwo Poznańskie, Poznań 1970; B. Koszel, Mitteleuropa rediviva? Europa Środkowa i Poludniowo-Wschodnia w polityce zjednoczonych Niemiec, Wydawnictwo Instytut Zachodni, Poznań 1999; W. Jarząbek, Polska Rzeczpospolita Ludowa wobec polityki wschodniej Republiki Federalnej Niemiec w latach 1966-1976. Wymiar dwustronny i międzynarodowy, Instytut Studiów Politycznych PAN, Warszawa 2011.

25 Po wojnie wskaźniki wymiany z obszarem wschodnim zaczęły spadać, aż w roku 1988 osiągnęły 9\%. Austria w naturalny sposób zainteresowała się rozwijającymi się rynkami EFTY, kierując tam $46 \%$ swojej produkcji, a także obszarem WE, gdzie wysyłano systematycznie przez kolejne dekady ponad $50 \%$ wartości produkcji.

26 K.E Meyer, Foreign Direct Investment in the Early Years of Economic Transition: a Survey, „Economics of Transition” 1995, t. 3, s. 310.

27 B. Koszel, Niemcy wobec Europy Środkowej i Poludniowo-Wschodniej w drugiej połowie XIX i w XX w. (do 1989 r.): koncepcje działań i próby organizacji polityczno-gospodarczej, „Przegląd Zachodni" 1997, nr 1, s. 93-116; Ch. Maier, Whose Mitteleuropa. Central Europa between Memory and Obsolescence, „Austrian in the New Europe. Contemporary Austrian Studies” 1993, t. 1, s. 8-19; A. Kożuchowski, Pośmiertne dzieje Austro-Węgier: obraz monarchii habsburskiej w piśmiennictwie międzywojennym, Wydawnictwo Neriton, Warszawa 2009.

28 B. Kreisky, Dwudziestolecie traktatu państwowego, „Austria-Polska. Czasopismo Gospodarczo-Społeczne" 1975, nr 94, s. 15. 
Zainteresowanie austriackich podmiotów gospodarczych obszarem wschodnim wynikało także z potrzeby zwiększenia rynków zbytu na towary austriackie, tworzenia możliwości wejścia na nowe rynki w regionie, niskimi kosztami surowców i płac, a także zwiększenia konkurencyjności na rynku Wspólnot Europejskich. Zagrożenia, jakie wskazywali potencjalni inwestorzy, wiązały się z wysokim ryzykiem wynikającym z niestabilnej sytuacji politycznej, zmienną makroekonomią, zmianami cen na rynkach na skutek odgórnych regulacji, zmianami praw dotyczących własności, ograniczonym dostępem i możliwościami eksportu dóbr, niską produktywnością i kosztochłonnością, biurokracją, zaniedbaniami w rozwoju infrastruktury i telekomunikacji. Stąd początkowo skłonność do zawierania umów kontraktowych, na czas ograniczony ${ }^{29}$. Stabilizacja polityczna widoczna $\mathrm{w}$ okresie détente, idąca $\mathrm{w}$ ślad za rozwojem gospodarczym Polski, była ważnym argumentem na rzecz rozwoju dotychczasowych kontaktów. Państwa wschodnie, w tym Polska, zintensyfikowały działania mające na celu podpisanie umów handlowych mogących bądź uzupełnić deficyt towarów, bądź zapewnić dostęp do nowych technologii ${ }^{30}$. Dodatkowym utrudnieniem decyzyjności na poziomie centralnym była działalność Rady Wzajemnej Pomocy Gospodarczej (RWPG). Struktura ta narzucała ograniczenia w podejmowaniu niezależnych decyzji gospodarczych, chociażby poprzez nakładanie na poszczególne kraje zobowiązań w ramach planów wieloletnich ${ }^{31}$. Podejmowanie inicjatyw dwustronnych miało na celu łagodzenie skutków ekonomicznych toksycznych relacji, w jakich kraje wschodnie tkwiły ze względu na decyzje płynące z Moskwy ${ }^{32}$.

Cele podejmowane przez dyplomację austriacką były w widoczny sposób zbieżne z polską koncepcją współpracy z państwami zachodnimi. Największym atutem był neutralny charakter państwa austriackiego. Obserwując napięcia w relacjach Wschód-Zachód, Polska starała się wypracować własną drogę współpracy z państwami zachodnimi $^{33}$. Zasadnicze cele kompleksowego rozwoju gospodarczego doprecyzowano w latach siedemdziesiątych XX wieku. Skupiały się na trzech ważnych kierunkach: 1. Utrzymania poprawnych relacji z Francją, RFN, Stanami Zjednoczonymi i państwami skandynawskimi; 2. Poszukiwania i utrzymania zewnętrznych źródeł zasilania gospodarki i pozyskiwania nowych kredytów inwestycyjnych; 3. Pozyskiwania dostępu do najnowszych technologii, dzięki czemu możliwa była modernizacja gospodarki ${ }^{34}$. Cele austriackie były zbieżne z 2. i 3. punktem polskiego planu rozwoju.

29 R. Gatling, Foreign Investment in Eastern Europe: Corporate Strategies and Experiences. Research Report, Economist Intelligence Unit, London 1993, s. 17.

30 M. Poniatowska-Jaksch, Przemysłowe bezpośrednie inwestycje zagraniczne- źródtem konkurencyjności regionu, Polskie Wydawnictwo Ekonomiczne, Warszawa 2006, s. 212.

31 R. Skobelski, PRL w Radzie Wzajemnej Pomocy Gospodarczej w latach 1956-1970, „Kwartalnik Historyczny" 2007, nr 3, s. 49-90.

32 E. Cyrson, Korporacje wielonarodowe. Prawidłowości ekspansji zagranicznej, Państwowe Wydawnictwo Naukowe, Warszawa 1981, s. 11-33.

33 A. Skrzypek, Dyplomacja polska między Wschodem a Zachodem (1976-1981), w: W. Materski, W. Michowicz (red.), Historia dyplomacji polskiej, 1944/1945 - 1989, t. 6, Polski Instytut Spraw Międzynarodowych, Warszawa 2010, s. 738.

34 A. Kisztelińska-Węgrzyńska, Bruno Kreisky. Polityka zagraniczna..., s. 199. 
Polityka inwestycyjna Austrii była oparta na stworzeniu warunków politycznych i prawnych do budowy otoczenia zapewniającego rozwój i wzajemne korzyści ${ }^{35}$. Kołem zamachowym miały być udzielane Polsce kredyty. Była to szczególna forma inwestycji tzw. kapitałowych lub finansowych ${ }^{36}$. Kredyty austriackie wiązały się z potrzebą pozyskiwania przez Warszawę kapitału z kilku źródeł przy jednoczesnym wprowadzeniu w Polsce zasad nowej polityki kredytowej ${ }^{37}$. Wiele państw proponowało usługi finansowe powiązane $\mathrm{z}$ inwestycjami bezpośrednimi. Wejście Polski do GATT otworzyło nowe możliwości ekonomiczne ${ }^{38}$. Austria kierowała przekazywane środki w określone sektory produkcji. Na początku lat siedemdziesiątych Polska miała otrzymać kapitał na rozwój głównie infrastruktury przemysłu wydobywczego i chemicznego. Kredyty udzielane przez Austrię dzieliły się na kilka podstawowych grup. Duża pula służyła finansowaniu inwestycji. Kolejne sumy były przeznaczane na zakup surowców i półproduktów. Trzecią grupę stanowiły kredyty na artykuły konsumpcyjne ${ }^{39}$. U schyłku lat siedemdziesiątych całkowita kwota kredytu z Austrii wyniosła 23,5 mld szylingów ${ }^{40}$. Do 1979 roku wydano tylko $360 \mathrm{mln}$, głównie na artykuły spożywcze.

Wybór poszczególnych sektorów, w jakich decydowała się inwestować Austria, wiązał się z analizą aktywności innych państw zachodnich na obszarze Polski. Jednakże był zbieżny z tendencją opisywaną przez Van der Wee, czyli wsparciem dla branż związanych z przemysłem ciężkim: górnictwa, hutnictwa, metalurgii. Szacowano możliwości zasobów surowcowych, kadr, zaplecza i potencjalnych rynków zbytu. Poza celami długofalowymi należy wymienić także cele doraźne, powstałe w wyniku reakcji na bieżącą sytuację bądź narastające kryzysy, jak choćby podczas wydarzeń z lat 1980-198141. Wówczas skupiono się na zapewnieniu realizacji zobowiązań z tytułu dostaw, bez których gospodarka austriacka mogła ponieść duże straty. W zasadzie to Austriacy byli inicjatorami rozmów bezpośrednich, prowadzonych przez przedstawicieli przedsiębiorstw, dzięki którym pomijano konsultacje z osobami niemającymi uprawnień decyzyjnych.

35 J.H. Dunning, The Prospects for Foreign Direct Investments in Eastern Europe, „Discussion Papers in International Investment and Business Studies" 1999, nr 155.

36 J. Witkowska, Bezpośrednie inwestycje zagraniczne w warunkach stowarzyszenia i przyszłego członkostwa w WE, Państwowe Wydawnictwo Ekonomiczne, Warszawa 1993, s. 32.

37 J. Gajdek, Der mittelbare Nachbar. Österreichvorstellungen in Polen 1970-1995, w: O. Rathkolb, O.M. Maschke, S.A. Lütgenau (red.), Mit anderen Augen gesehen. Internationale Perzeptionen Österreichs 1955-1990 (Österreichische Nationalgeschichte nach 1945/2), Böhlau Verlag, Wien-Köln-Weimar 2002, s. 661.

38 Od 1957 roku Polska była obserwatorem w strukturze określonej przez Układ w Sprawie Ceł i Handlu, w 1960 roku została członkiem stowarzyszonym. Uzyskane przez Polskę w 1967 roku pełne członkostwo w GATT umożliwiło wprowadzenie do tekstu umowy z 1968 roku klauzuli najwyższego uprzywilejowania w wymianie towarowej między Austrią a Polską.

39 Przy całkowitej kwocie kredytu 23,5 mld szylingów, do 1979 roku 3 mld przeznaczono na zakup dóbr inwestycyjnych w Austrii, 4,7 mld na zakup wyrobów stalowych, 4,3 mld, na licencje i kooperację w ramach współpracy z przedsiębiorstwami austriackimi.

40 A. Kisztelińska-Węgrzyńska, Bruno Kreisky. Polityka zagraniczna..., s. 222.

${ }_{41}$ Niepokoje społeczne, wzrost migracji, wzrost cen, strajki i opóźnienia w dostawach przewidzianych w umowach dwustronnych doprowadziły do korekty założonych planów gospodarczych. A. Kisztelińska-Węgrzyńska, Bruno Kreisky. Polityka zagraniczna..., s. 271-275. 
Tego typu dialog wpisywał się również w założenia sformułowane w uchwale Rady Ministrów z 20 marca 1976 roku dotyczącej realizacji zadań Aktu końcowego KBWE ${ }^{42}$, tj. przekazania większych kompetencji niższym organom decyzyjnym i rozszerzenia współpracy gwarantującej zyski z tymi państwami zachodnimi, które były sygnatariuszami aktu.

\section{Inwestycje austriackie w Polsce}

Przygotowanie gruntu pod przyszłe inwestycje opierało się na stworzeniu warunków prawnych i rozpoznania rynku w zakresie możliwości produkcyjnych i nabywczych. $\mathrm{W}$ pierwszych latach powojennych relacji gospodarczych władze austriackie zakładały przyjęcie formuły zawierania kontraktów przez przedsiębiorstwa i instytucje związane z zakupem i sprzedażą określonych produktów i usprawnienia tej wymiany przez uprawnione do tego władze państwowe obydwu stron. Wśród towarów austriackich, jakie były sprowadzane na mocy pierwszej ważnej umowy handlowej z 1954 roku, których wartość przekraczała 0,5 mln dolarów, najważniejsze miejsce zajmowały wyroby ze stali szlachetnej. Dostawy polskie obejmowały różne grupy produktów, lecz ich wartość nie przewyższała, w każdej z nich, 100 tys. dolarów. Najważniejszym polskim produktem eksportowym był węgiel. Początkowo, aby ułatwić wymianę towarową, Banki Narodowe obydwu państw udzieliły sobie wzajemnie kredytu technicznego w wysokości 2 mln dolarów dla towarów priorytetowych i $0,5 \mathrm{mln}$ dla pozostałych. Według Rocznika Statystycznego z roku 1956 Austria zajmowała siódme miejsce w strukturze polskiego handlu zagranicznego (2,5\%, czyli niewiele mniej niż z RFN - 2,9\%). Do połowy lat pięćdziesiątych bilans handlowy był dla Polski korzystny ${ }^{43}$.

W liberalizacji, jaka uwidoczniała się od początku lat siedemdziesiątych w krajach komunistycznych, Wiedeń widział szansę dla Europy Środkowej. Tutaj, a nie w całkowitym otwarciu zachodnioeuropejskiej wspólnoty gospodarczej, poszukiwano dla Austrii nowej międzynarodowej roli ${ }^{44}$. Wiele uwagi poświecono potencjalnej współpracy z Czechosłowacją, która była krajem tranzytowym. Rozmowy te miały na celu rozszerzenie współpracy $\mathrm{w}$ regionie ${ }^{45}$. Strona czechosłowacka domagała się rozmów trójstronnych i większych korzyści z tytułu transferu polskich dóbr. Władze austriackie starały się być pośrednikiem i unikały spotkań w większym gronie ${ }^{46}$. Nieufność państw wschodnich wobec siebie była wielkim mankamentem podczas spotkań wielostronnych. Ograniczone możliwości prowadzenia dialogu w ramach struktur stworzo-

42 M. Geldner, Przyczynek do teorii zagranicznych inwestycji zagranicznych, „Monografie i Opracowania SGPiS", Warszawa 1986, nr 193.

43 Rocznik Statystyczny 1956, Wydawnictwo Głównego Urzędu Statystycznego, Warszawa 1956.

44 B. Kreisky, Politik braucht Visionen, Aufsatze, Reden und Interviews zu aktuellen weltpolitischen Fragen mit einem Vorwort von Walter Jens, Verlag-Beethoven-Haus, Bonn 1982, s. 116-17. 45 Strona czechosłowacka domagała się rozmów trójstronnych i większych korzyści z tytułu transmisji polskich dóbr. Władze austriackie starały się być pośrednikiem i unikały spotkań w większym gronie. W sytuacji, kiedy napotykano przeszkody podczas negocjacji, kierowano temat pod obrady KBWE lub stosowano inne formy nacisku.

46 A. Kisztelińska-Węgrzyńska, Bruno Kreisky. Polityka zagraniczna..., s. 225. 
nych przez ZSRR przenosiły się na nieumiejętność podejmowania wspólnych decyzji na forum międzynarodowym. Należy podkreślić, że brak tendencji do integracji obszaru Europy Środkowo-Wschodniej niweczył ponadnarodowe projekty gospodarcze inicjowane przez Wiedeń. Austria miała zbyt mały wpływ na przebieg negocjacji czy możliwość oddziaływania na pozostałych partnerów. Władze austriackie oceniły, że państwa wschodnie będą w stanie samodzielnie wypracować wspólne stanowisko w kwestii projektów realizowanych w większym gronie. Tymczasem kraje te nie miały dobrych doświadczeń w tym zakresie ani też nie formułowały tak ukierunkowanych celów politycznych.

Konsekwentnie przez cały okres powojenny podczas planowania wspólnych inwestycji władze austriackie zwracały uwagę na słabą sieć komunikacyjną i potrzebę rozwoju infrastruktury. Zarówno transport kolejowy, drogowy, jak i wodny wymagały rozszerzenia, aby dalsze inwestycje mogły się rozwijać z sukcesem. Dotychczasowe kanały komunikacyjne były mało wydajne, zaproponowano więc rozbudowę dróg transportu wodnego poprzez kanał Dunaj-Men-Ren i Dunaj-Odra-Laba.

Jednym z elementów współpracy na rzecz rozszerzenia inwestycji bezpośrednich były wizyty ekspertów austriackich. Analizowano zasoby, jakimi Polska dysponowała, prognozowano możliwości dotyczące poszukiwania nowych złóż, opłacalność zakupu polskich surowców i nakładów inwestycyjnych, jakie już zostały poniesione. Podczas jednej z wizyt eksperckich dyrektor generalny koncernu Voest Alpine dr Herbert Koller przygotował w listopadzie 1973 roku analizę możliwości inwestycyjnych w Polsce i opinię na temat przedsiębiorstw, z którymi Austria miała rozpocząć wspólne projekty. Koller sugerował m.in. pracę nad umową dotyczącą zakupu surowców, gorąco popierał współpracę Voith AG z nowo powstałymi Zakładami Celulozowo-Papierniczymi w Kwidzynie, które były atrakcyjne także dla innych zagranicznych inwestorów ${ }^{47}$.

Istotnym elementem współpracy przekładającej się na decyzje gospodarcze były cła. Strona polska obawiała się planowanego w styczniu 1977 roku zniesienia barier celnych pomiędzy Austrią i obszarem EWG. Zapowiedziano w związku z tym przygotowanie przepisów regulujących wymianę towarową na warunkach korzystnych dla Polski. Po zakończeniu wizyty w Polsce kanclerza Bruno Kreisky'ego w 1976 roku podpisano w Wiedniu odnoszący się do tych warunków traktat handlowy. Była to Umowa wieloletnia $w$ sprawie obrotu towarowego i platniczego oraz wspótpracy gospodarczej między Rzadem Polskiej Rzeczypospolitej Ludowej a Austriackim Rzadem Zwiazkowym z 22.09.1976 roku. Na jej podstawie rozwijano przedsiębiorstwa zajmujące się handlem ${ }^{48}$. Polska i Austria zobowiązały się dostosować postanowienia GATT do wzajemnych obrotów handlowych, również w zakresie klauzuli najwyższego uprzywilejowania. Zaopatrzono ją w Protokół Dodatkowy uzupełniający wskaźniki wzajemnej wymiany towarowej. Dla Polski taki protokół był korzystny ze względu na stałą specyfikację towarów i możliwość długofalowego planowania produkcji.

47 Stiftung Bruno Kreisky Archiv, (dalej: StBKA), Österreichische Botschaft Warschau. Resuméprotokoll über die Gespräche anläßlich des offiziellen Besuches des BK, 25.6.1973, Länderbox Polen Box 5.

48 J. Witkowska, Pojęcie przedsiębiorstwa międzynarodowego, „Acta Universitatis Lodziensis. Folia Oeconomica" 1988, nr 82. 
Po 1975 roku Austria zniosła ograniczenia ilościowe w handlu z krajami wschodnimi. W ich miejsce wprowadzono obowiązek wizowania faktur (Vidierungsverfahren), na liście towarów objętych tym przepisem znalazło się 200 pozycji. Bilans wymiany gospodarczej w latach siedemdziesiątych XX wieku miał także negatywną stronę dla Polski. Eksport z naszego kraju do Austrii ciągle wykazywał niższą dynamikę wzrostu (2,5-krotnie) niż importu z Austrii. Ujemne dla Polski saldo bilansu handlowego wyniosło około 50 mld szylingów. Strona polska systematycznie zastępowała surowce artykułami rolno-spożywczymi. Udział surowców w ogólnym eksporcie zmalał do 1980 roku o $54 \%{ }^{49}$. Do 1981 roku wymianę z zagranicą prowadziło 61 instytucji, z których 19 podporządkowano Ministerstwo Handlu Zagranicznego, a reszta została rozproszona między inne resorty i instytucje centralne ${ }^{50}$.

Efektem bezpośrednich spotkań i wizyt w Polsce było przygotowanie gruntu prawnego do dalszej współpracy ${ }^{51}$. Dla strony polskiej niezwykle ważny był dostęp do nowoczesnych technologii warunkujących usprawnienie i zmiany kosztów produkcji. $\mathrm{W}$ połowie lat siedemdziesiątych powstało jedno z ważniejszych polsko-austriackich porozumień handlowych po II wojnie światowej - Umowa o dostawach energii elektrycznej z Polski do Austrii oraz o imporcie do Polski dóbr inwestycyjnych i urządzeń na warunkach kredytowych ${ }^{52}$. Umawiające się strony przyjęły, że zostaną stworzone odpowiednie warunki umożliwiające import do Polski dóbr inwestycyjnych w ramach austriackiego systemu finansowania eksportu. Wymieniono kwotę 3 mld szylingów do dyspozycji w kolejnych trzech latach. Powołano także przedsiębiorstwa zarówno po stronie polskiej, jak i austriackiej mające zawrzeć wieloletnie kontrakty na dostawy energii z Polski do Austrii. Nowe strategie ekonomiczne okazały się w dużej mierze strategią pobudzania wzrostu przez import finansowany z kredytów, dawało to impulsy dla równoczesnego wzrostu konsumpcji i inwestycji, bez stworzenia odpowiedniego potencjału eksportowego, by spłacić pożyczone środki ${ }^{53}$. Polityka ta zakładała kredytowanie nie tylko dóbr inwestycyjnych, lecz także surowców do bieżącej produkcji i środków konsumpcji, zwłaszcza pasz do hodowli zwierząt. Nierównowagę ekonomiczną w tym okresie pogłębiało nadmierne inwestowanie, podwyżki płac dokonywane niezależnie od poprawy wydajności pracy i przekonanie, że motorem reform gospodarczych był przemysł ciężki. Polska jednak przestała być eksporterem energii, stała się

49 E. Bryl-Warewicz, Stosunki polsko-austriackie po II wojnie światowej, w: W. Śladkowski, A.A. Witusik (red.), Wiktoria wiedeńska i stosunki polsko-austriackie w latach 1683-1983, Wydawnictwo UMCS, Lublin 1983, s. 267.

50 L. Jasiński, Bliżej centrum czy na peryferiach..., s. 271.

51 J. Stairbacher, Austriacko-polskie stosunki gospodarcze, „Austria-Polska. Czasopismo Społeczno-Kulturalne" 1973, s. 13. Kolejna umowa handlowa zawarta 6 września 1973 roku na okres dziesięciu lat regulowała rozwój współpracy gospodarczej, przemysłowej i naukowo-technicznej, a także zasady kooperacji przemysłowej obydwu państw. A.Kisztelińska-Węgrzyńska, Bruno Kreisky. Polityka zagraniczna..., s. 214-216.

52 Dodatkowo podpisano także Wieloletni Program dalszego rozwoju wspótpracy gospodarczej, przemysłowej i naukowo-technicznej. W latach 1973-1974 podpisano łącznie siedem traktatów dwustronnych.

53 S. Grużewski, Problemy specjalizacji eksportowej, „Handel Zagraniczny” 1982, nr 4, s. 71. 
jej importerem netto ${ }^{54}$. Zakładana przez Austriaków emancypacja poprzez poprawę warunków gospodarczych przyniosła w tym przypadku efekt odwrotny od zamierzonego i większe uzależnienie od dostaw z ZSRR.

Wpływ inwestycji austriackich na przedsiębiorczość i stosunki społeczne w Polsce był ograniczony. Zakładane inicjatywny na rzecz poprawy przedsiębiorczości napotykały utrudnienia organizacyjne, biurokrację i brak decyzyjności na poziomie regionów, województw ${ }^{55}$. Polskie władze planowały sporą niezależność przekazać wielkim organizacjom gospodarczym tzw. WOG-om. Działające kombinaty i przedsiębiorstwa miały wpływ na narzędzia w postaci kształtowania cen, kursów walut, zasad opodatkowania i wykonywania międzynarodowych zobowiązań państwa. Ostatecznie jednak WOG-i wpływały na system ekonomiczno-finansowy polskich przedsiębiorstw tylko w niewielkiej mierze decentralizując system kierowania gospodarką państwa ${ }^{56}$. Paradoksem „reformy wogowskiej" okazało się osłabienie zainteresowania wielkich organizacji gospodarczych wytwarzaniem na eksport ${ }^{57}$. Produkowane towary były gorsze jakościowo, nie spełniały wymogów zagranicznych nabywców, a ich produkcja przynosiła straty. Stąd decyzje, aby kierować je na rynek wewnętrzny. Zniesienie ograniczeń na prowadzenie handlu zagranicznego przez przedsiębiorstwa produkcyjne, podobnie jak swoboda obrotu walutowego, nastąpiły dopiero w drugiej połowie 1989 roku po zainicjowaniu przejścia od gospodarki komunistycznej do rynkowej ${ }^{58}$.

Analizując możliwości polskiej gospodarki i światowe trendy rozwoju, strona austriacka próbowała konkurować z Włochami, Francuzami i Amerykanami w zakresie inwestycji w przemyśle motoryzacyjnym. Jedną z pierwszych ważniejszych inwestycji austriackich podjętych w tym zakresie w 1973 roku była współpraca z koncernem Steyr-Daimler dotycząca produkcji maszyn budowlanych, wywrotek i ciągników siodłowych. Dwa lata później współpraca została rozwinięta na podstawie dodatkowej umowy z firmą „Polmot”. Chodziło o budowę ciężarówek o ładowności od 18 do 32 ton, wyposażonych w silniki o mocy $450 \mathrm{KM}$. Na realizację tej umowy bank austriacki udzielił kredytu ${ }^{59}$. Możliwości konkurowania na gruncie polskim firm austriackich z włoskimi, francuskimi i amerykańskimi były ograniczone i wynikały z preferencji polskich decydentów.

Strona austriacka poszukiwała tzw. sektorów niszowych, mniej atrakcyjnych dla pozostałych krajów zachodnich. Trudno bowiem było przewidywać trendy łączące wymianę gospodarczą państw centralnie planowanych i wolnorynkowych. W każdym

\footnotetext{
54 L. Jasiński, Blizej centrum czy na peryferiach..., s. 252.

55 Owocna wizyta państwowa, „Austria-Polska. Czasopismo Gospodarczo-Kulturalne” 1975, nr 94, s. 11.

56 D. Ledworowski, U. Płowiec, Problemy handlu zagranicznego w organizacjach gospodarczych przemystu, w: K. Cholewicka-Goździk (red.), Wielkie organizacje gospodarcze. Doświadczenia z lat 1973-1975, Państwowe Wydawnictwo Ekonomiczne, Warszawa 1977, s. 278-302.

57 L. Jasiński, Bliżej centrum czy na peryferiach..., s. 252.

58 Z. Piotrowski, Zmiany w systemie kierowania polskim handlem zagranicznym „Stosunki Międzynarodowe" 1989, nr 9, s. 109-121.

59 A. Wieczorkiewicz, Kooperacja przemysłowa Polski z rozwiniętymi krajami kapitalistycznymi, Wydawnictwo Szkoły Głównej Planowania i Statystyki, Warszawa 1980, s. 126-127.
} 
z państw wschodnich dominowały odmienne tendencje rozwoju i potrzeb w zakresie inwestycji. Choć pozornie wydawało się, że zasoby kadrowe i ograniczone możliwości surowcowe skłaniały do dominacji przemysłu tekstylnego i elektronicznego na obszarze wschodnim, tak się nie stało. W 1975 roku doszło do podpisania ważnej umowy dotyczącej współpracy na rynkach trzecich. Polskie przedsiębiorstwo „Polimex-Cekop” i austriackie „Voest Alpine” zdecydowały o budowie fabryki melaminy, podejmując przy tym współpracę z koncernem Linz $\mathrm{AG}^{60}$. Zachęciło to inne polskie przedsiębiorstwa do podpisywania podobnych umów w kolejnych latach. Austriacy wysoko oceniali możliwości pozyskiwania w Polsce wykfalifikowanych robotników, których udział w takich inwestycjach na rynkach krajów trzecich był kluczowy ${ }^{61}$. Wśród najważniejszych kooperacji wymienić można: polski „Kolmex” i austriacki „Plasser und Theurere”, „Metronex” i „Goerz-Elektro”, „Elektrim” i „Schrack” i „Dvorak und Kobler AG”, „Armatura” i „Gustav Schmiedl”, „Stalexport” i „Voest Alpine” wraz z „Vereinigte Edelstahlwerke”. Najbardziej intratnym przedsięwzięciem była umowa pomiędzy „Węglokoksem” i „Voest Alpine” dotycząca eksportu polskiego węgla i koksu. W większości umów pośredniczył polski Bank Handlowy z siedzibą w Warszawie ${ }^{62}$.

Rozwój inwestycji bezpośrednich wiązał się z zakupem licencji. Tylko w ciągu pierwszych pięciu lat dekady Edwarda Gierka nabyto ogółem 370 licencji, podczas gdy w poprzednich dwudziestu latach tylko 218. Połowa zakupionych rozwiązań technologicznych związana była z preferowanym przez Austriaków przemysłem maszynowym. Spotkania roboczych grup konsultacyjnych z Dyrektorem Departamentu Politycznego Franciszkiem Ceską u schyłku lat siedemdziesiątych dotyczyły także wdrażania rozwiązań technicznych ${ }^{63}$. Wspólne ustalenia przygotowali przedstawiciele urzędów patentowych, którzy opracowali regulamin dotyczący ochrony własności przemysłowej. Ułatwiło to stronie polskiej dostęp do dokumentacji zdeponowanej w międzynarodowym centrum INPADOC, którego siedziba znajdowała się w Wiedniu ${ }^{64}$.

Choć licencje wdrażano nieumiejętnie, to stanowiły one duży impuls do rozwoju polskiej gospodarki. Udział maszyn i urządzeń pochodzących z państw zachodnich stanowił w polskim przemyśle do $30 \%$. W stosunku do poprzednich dekad aparat produkcyjny został wyraźnie unowocześniony ${ }^{65}$. Niestety brak reform systemowych ograniczył wykorzystanie powiększonych zdolności produkcyjnych. Warto również dodać, że kierowane do krajów Europy Środkowo-Wschodniej technologie nie dotyczyły innowacji (informatyki, biotechnologii, technologii w zakresie nowych materiałów), lecz głównie

\footnotetext{
60 H. Apfalter, Koncern VOEST-ALPINE jako partner polskiej gospodarki, „Austria-Polska. Czasopismo Gospodarczo-Kulturalne" 1979, t. 107, s. 55.

61 J. Staribacher, Austriacko-polskie stosunki gospodarcze, „Austria-Polska. Czasopismo Gospodarczo-Kulturalne" 1979, nr 107, s. 9.

62 P. Franaszek, Die Handelsbeziehungen zwischen der Volksrepublik Polen und Österreich in der Zeit von 1945-1989, w: G. Enderle-Burcel (red.), Zarte Bande: Österreich und die europäischen planwirtschaftlichen Länder. Delicate relationship, WUV-Universitätsverlag, Wien 2006, s. 193.

63 Archiwum Ministerstwa Spraw Zagranicznych (dalej: AMSZ) D. IV Austria, z.1/84, w. 3. Notatka informacyjna z 22 XI 1978 roku.

64 AMSZ D. IV Austria, z.1/84, w. 3. Pismo B. Kulskiego z 21VIII 1978 roku.

65 L. Jasiński, Blizej centrum czy na peryferiach..., s. 270.
} 
przemysłu maszynowego. W latach osiemdziesiątych 95\% projektów związanych z rozwojem najnowszych technologii realizowanych było wyłącznie pomiędzy krajami rozwiniętymi. Tylko $13 \% \mathrm{z}$ nich zakładało włączenie w przyszłości krajów rozwijających się. Zaważyła rywalizacja zimnowojenna i względy polityczne uniemożliwiające współpracę naukową i technologiczną ${ }^{66}$.

Poprawa sytuacji gospodarczej w Polsce idąca w ślad za rozwojem stosunków dwustronnych była widoczna ${ }^{67}$. W świetle statystyk obroty handlowe między Polską a Austrią zmieniły się znacząco na przestrzeni kilkunastu lat. W roku 1970 eksport z Polski wyniósł 232,2 mln zł dew. Natomiast w 1980 roku 834,9 mln zł dew. W tym samym czasie import do Polski wzrósł z 248,6 mln zł dew. do 1749,6 mln zł dew. Największy ujemny bilans wymiany handlowej do Polski miał miejsce w roku 1976 i wyniósł - 1452,8 mln zł dew. (dla porównania w roku 1970 - tylko - 16, 3 mln zł dew.). Pogarszająca się sytuacja polityczno-społeczna zadecydowała o przeniesieniu wielu projektów austriackich do Węgier i Czechosłowacji. U schyłku lat siedemdziesiątych jedynie czterech inwestorów, którzy wbrew pogarszającej się sytuacji planowało dalszą współpracę: Voest Alpine (7 projektów), Klin Union (2 projekty), Verenigte Metallwerke (1 projekt), Waagner Brio (1 projekt) ${ }^{68}$.

Narastające u schyłku lat siedemdziesiątych napięcie w relacjach USA-ZSRR ograniczało aktywność Polski nie tylko politycznie. W wyniku drugiego kryzysu energetycznego ceny surowców wzrosły wyraźnie. Przewidując spadek wydobycia i ograniczenia dostaw surowcowych z Polski, rozwijano polsko-austriacką współpracę podczas spotkań nieoficjalnych, których efektem była kolejna pula kredytów. Austria dążyła do zwiększenia importu polskiej energii i surowców. W gronie państw wschodnich ZSRR i Polska produkowały systematycznie od początku lat siedemdziesiątych więcej energii niż były w stanie wykorzystać. Zdaniem ekspertów poza samą produkcją, która systematycznie wzrastała, należało zwrócić uwagę na bogate polskie złoża. Państwa wschodnie nie poszukiwały alternatywy w pozyskiwaniu energii, w niewielkim stopniu wykorzystywały również energię jądrową. Największą wspólną inwestycją było włączenie polskich przedsiębiorstw do budowy gazociągu West-Austria-Gasleitung, powstającego przy udziale firm francuskich ${ }^{69}$. Ponadto zaproponowano współpracę Budimexu przy odbudowie mostu Reichsbrücke w Wiedniu, powołując się na dotychczasowe doświadczenia w zakresie budowy konstrukcji stalowych. Atrakcyjna była dla Polaków również inwestycja związana z budową kopalni węgla Oberdorf-Voitsberg. Wśród ważnych projektów na rynkach państw trzecich wymieniano $\mathrm{m}$. in. budowę cementowni w Turcji i Tunezji, budowę rafinerii olejów sztucznych w Algierii czy zakładów nawozów fosforowych w Jugosławii, budowy cukrowni w Egipcie, Ekwadorze i Filipinach ${ }^{70}$. Największe roz-

${ }^{66}$ J. Witkowska, Bezpośrednie inwestycje zagraniczne w Europie Środkowowschodniej. Próba interpretacji na gruncie teorii bezpośrednich i nwestycji zagranicznych i teorii integracji, Wydawnictwo Uniwersytetu Łódzkiego, Łódź 1996, s. 161.

67 J. Kaliński, Z. Landau, Gospodarka Polski w XX wieku, Polskie Wydawnictwo Ekonomiczne, Warszawa 1998, s. 281-283.

68 A. Kisztelińska-Węgrzyńska, Bruno Kreisky. Polityka zagraniczna..., s. 224.

69 H. Chądzyński, Bliscy partnerzy. Polska - Austria, „Życie Warszawy” 1979, nr 276, s.5.

70 A. Kisztelińska-Węgrzyńska, Bruno Kreisky. Polityka zagraniczna..., s. 216. 
wijające się wówczas inwestycje austriackie w Polsce to Przedsiębiorstwo Celulozowo-Papiernicze w Kwidzynie, wartość nakładu austriackiego to 1,5 mld szylingów, Petrochemia w Płocku - nakład 1,5 mld szylingów i Huta im. Lenina - 350 mln szylingów ${ }^{71}$.

Wśród zjawisk niekorzystnych na początku lat osiemdziesiątych wymieniano stosowanie przez Austrię barier taryfowych w sektorze przemysłu spożywczego. Zaostrzono wymogi sanitarne i celne, a także nałożono ograniczenia dla importerów współpracujących z Europą Środkową ${ }^{72}$. Osłabieniu uległa koniunktura wymiany wyrobów hutniczych i chemicznych, natomiast poprawiła się organizacja własnych sieci dystrybucji cementu i obuwia $^{73}$. Austria tworzyła również pewne bariery dotyczące polityki celnej. Według austriackich przepisów import do Austrii traktowany był jako przywóz towarów i nie podlegał usługom celnym. Zwiększono podatek obrotowy na tzw. towary luksusowe: dywany, aparatura hi-fi, samochody, biżuteria, co wpłynęło hamująco na polski eksport ${ }^{74}$.

Wywołane kryzysem lat 1980/1981 zagrożenie niemożnością wypełniania zobowiązań dotyczących eksportu energii z Polski, była dla Austrii niepokojące. Jako alternatywę Austriacy proponowali budowę elektrowni atomowej w Polsce. Finansowanie inwestycji miało pochodzić z kilku źródeł. Czechosłowacja lub Węgry miały być państwami tranzytowymi. Politycznie uzasadniano ten projekt koniecznością rozwoju współpracy energetycznej Wschód-Zachód. Tu kolejny raz zawiodła możliwość porozumienia państw wschodnich ${ }^{75}$. Austriacy zakładali, że wystarczy dać tym krajom swobodę działania w swoim gronie ${ }^{76}$. Przedstawiając ten projekt na forum, zwracano uwagę na duże korzyści polityczne i gospodarcze: wzmocnienie lokalizacyjne i przewagę gospodarki polskiej, stymulowanie inwestycji wewnątrz integrującego się obszaru, tworzenie zachęty do podjęcia na tym obszarze inwestycji przez kraje trzecie, wzmocnienie procesów modernizacyjnych i powolny proces restrukturyzacji, czyli dostosowania do współpracy w wolnorynkowych warunkach gospodarczych ${ }^{77}$.

Wśród mankamentów rozwijanej współpracy dominowały dysproporcje w systemach gospodarczych. Ogromna część środków dewizowych została w Polsce wydana w sposób nieuzasadniony. Wynikało to z wielu zaniedbań, braku wiedzy i możliwości, nieuczciwości i braku planowania ${ }^{78}$. Efektywność została ograniczona także na etapie projektowania. Nadmierny import rozwiązań technicznych oddziaływał ujemnie na pracę krajowych ośrodków badawczych i wdrożeniowych ${ }^{79}$. Prognozy gospodarcze zmu-

\footnotetext{
71 Ibidem, s. 216.

72 Z. Fallenbuchl, O sankcjach gospodarczych wobec Polski, „Kultura” 1983, nr 12 (435), s. 50-64.

73 AMSZ D. IV Austria, z.1/84, w. 3. Pismo B. Kulskiego z 21VIII 1978 roku, s. 6.

74 Ibidem.

75 O. Höll, Introduction, w: O. Höll (red.), Environmental Cooperation in Europe, Manchester University Press, Manchester 1994, s. 7-10.

76 P. Ullmann, Eine schwierige Nachbarschaft. Die Geschichte der diplomatischen Beziehungen zwischen Österreich und der Tschechoslowakei 1945-1968, Wiener Osteuropa Studien, Wien 2006, s. 140-166.

77 U. Brand, A. Pawloff, Climate Concerns in the Midst of Corporatist Interests. The Case of Austria, „Journal of Environmental Protection” 2014, t. 5, s. 786.

78 L. Jasiński, Bliżej centrum czy na peryferiach..., s. 274.

79 R. Rapacki, System gospodarczy a import techniki w Polsce, „Handel Zagraniczny” 1989, nr 4-5, s. 4-8.
} 
szały Austriaków do poszukiwania rozwiązań umożliwiających wyjście z impasu. Sytuacja, w której Polska przestałaby wypełniać swe zobowiązania, byłaby dla Austriaków nie do zaakceptowania. $\mathrm{W}$ połowie września 1980 roku strona polska poprosiła o dodatkową linię kredytową w wysokości 3,5 mld szylingów na zakup niezbędnych towarów potrzebnych do wypełnienia dotychczasowych zamówień i limitów związanych z poprzednimi kredytami. Jeszcze wówczas sprawa ta nie była przegrana, a strona austriacka nadal rozważała wsparcie poszczególnych gałęzi produkcji z nadzieją na kooperację i wspólne zyski w przyszłości ${ }^{80}$. Sytuacja pogorszyła się wraz z końcem roku $1980^{81}$. Podczas obrad grup mieszanych nadal wymieniano gałęzie przemysłowe i przedsiębiorstwa odpowiadające za wymianę handlową ze strony polskiej, lecz planowana współpraca z polskimi przedsiębiorstwami na rynkach trzecich uległa załamaniu w 1981 roku $^{82}$.

Lata kryzysu (1980-1981) zamroziły austriacką aktywność inwestycyjną. Od połowy lat osiemdziesiątych wznowiono wizyty grup roboczych. Strona polska intensywnie zabiegała o to od początku wprowadzenia stanu wojennego. Głównym zadaniem wymienionych grup było odtworzenie realizowanych wcześniej projektów na rynkach trzecich. W związku z katastrofalną sytuacją gospodarczą w Polsce wykonanie nowych zadań było niemożliwe. Austria, tak jak i pozostałe kraje zachodnie, przeniosła swe inwestycje do krajów sąsiednich ${ }^{83}$. Ostatnim akordem były ustalenia prawne dotyczące wspólnych działań w dziedzinie ochrony środowiska zawarte w dniu 24 listopada 1988 roku $^{84}$. Katastrofa w Czarnobylu zmobilizowała państwa w regionie do większej współpracy na rzecz przeciwdziałania skutkom dewastacji środowiska naturalnego ${ }^{85}$. Dotyczyła ona głównie wymiany naukowej i wdrażania rozwiązań technicznych mających ograniczyć skutki skażenia środowiska i ochrony zdrowia ${ }^{86}$.

\section{Rezultaty austriackich inwestycji bezpośrednich w Polsce}

Wymieniając rezultaty austriackich inwestycji bezpośrednich w Polsce, warto skupić się na trzech wątkach. Pierwszym jest wymiana handlowa generująca ogół warunków ekonomicznych umożliwiających podjęcie dalszej współpracy. Kolejnym efekty

\footnotetext{
80 A. Kisztelińska-Węgrzyńska, Bruno Kreisky. Polityka zagraniczna ..., s. 256.

81 D.T. Grala, Reformy gospodarcze w PRL (1982-1989). Próby ratowania socjalizmu, Wydawnictwo Trio, Warszawa 2005, s. 331-365.

82 P. Gutman, Joint-Ventures in Eastern Europe and the Dynamics of Reciprocal Flows in EastWest Direct Investments: Some New Perspectives, w: A.M. Patric, M. Svetlicic (red.), Foreign Investment in Central and Eastern Europe, Palgrave Macmillan, London 1993, s. 54-81.

83 G. Górniewicz, Determinanty i konsekwencje bezpośrednich inwestycji zagranicznych, „Studia z Zakresu Prawa, Administracji i Zarządzania" 2013, t. 3, s. 61-62.

${ }^{84}$ Umowa $w$ sprawie popierania i ochrony inwestycji z 24 listopada 1988 roku, opublikowana w Dzienniku Ustaw. Dz. U. 1989 nr 54 poz. 321. Obowiązuje do dziś.

85 J. Nocoń, Problematyka ekologiczna $w$ świadomości politycznej regionalnych elit władzy, w: A. Papuziński (red.), Decentralizacja, regionalizacja, ekologia, Wydawnictwo Uczelniane Wyższej Szkoły Pedagogicznej, Bydgoszcz 1998, s. 100.

86 V. Lauber, Austria: a Latecomer Which Became a Pioneer, w: M. Andersen, D. Liefferink (red.), European Enviornmental Policy. The Pioneers, Manchester University Press, Manchester 1997, s. 110.
} 
wspólnych inwestycji, trzecim zaś kooperacja gospodarcza na obszarze innych państw. Wszystkie te komponenty ujęte w porządku chronologicznym dają pewien obraz wspólnych działań w okresie powojennym. Politykę sąsiedztwa, czyli współpracę z państwami otaczającymi Austrię, formułowano i realizowano od początku lat sześćdziesiątych. Określono wówczas zasady, na jakich państwo austriackie miało uregulować stosunki z państwami komunistycznymi. W kolejnych dekadach Austria traktowana była jako lider państw małych i niezaangażowanych, głównie dzięki swej polityce aktywnej neutralności. Kierunek zmian zarówno w polityce zagranicznej, jak i reform wewnątrz kraju przywoływał w Austrii pytania o tożsamość. Westernizacja traktowana w kategoriach podążania w ślady obcych była w opozycji do przyjętej po 1955 roku zasady wieczystej neutralności. Dla Austriaków udział w strukturach politycznych i ekonomicznych integrującej się Europy był bezkrytycznym przyjmowaniem wzorów narzuconych z zewnątrz i stał w sprzeczności z zasadą samostanowienia państwa.

Austria była jednym $\mathrm{z}$ wielu państw, które inwestowały w państwach wschodnich. Dając początek nowym gałęziom produkcji, wspierała zmiany w strukturze gospodarczej Polski i pozostałych krajów Europy Środkowo-Wschodniej. Wpływ na stosunki społeczno-polityczne był widoczny i rosnący. Początkowo Polska znalazła się wśród państw objętych ze stronny państw EFTY (Europejskiego Stowarzyszenia Wolnego Handlu, do którego należała Austria) polityką autonomiczną, tzn. że handel zagraniczny realizowany był w najmniej korzystnych warunkach instytucjonalnych. W stosunku do Polski nie obowiązywała zasada najwyższego uprzywilejowania, nie obowiązywały także zasady niedyskryminacji i wzajemności. Zmuszało to rząd polski do większej aktywności w dziedzinie promocji i rozwoju inwestycji zagranicznych. Wymiernym efektem rozwoju relacji gospodarczych i zainteresowania ze strony austriackiej polskimi towarami było podpisanie deklaracji znoszącej ograniczenia ilościowe dla polskich produktów z 1 stycznia 1975 roku. Było to pierwsze porozumienie o takim charakterze podpisane przez polskie władze, stanowiące krok w stronę aktywnej i korzystnej polityki handlowej. Szczegółowe analizy ekonomiczne konsekwentnie wymieniały Polskę jako najważniejsze państwo w regionie, istotny obszar zbytu austriackich produktów i partnera dążącego do rozbudowy technologicznej ważnych sektorów produkcji.

Na początku lat siedemdziesiątych wzrost importu towarów austriackich był wyższy od poziomu z 1950 roku o ponad $400 \%$, eksport był na stałym poziomie, lecz również zanotował wzrost o $150 \%$. Miały na to wpływ zarówno porozumienia włączające Polskę do GATT, jak i rozbudowane rozmowy grup mieszanych ${ }^{87}$. Przygotowano przepisy regulujące wymianę towarową na warunkach korzystnych dla Polski, zaś kartą przetargową miała być ustawa z 14 maja 1976 roku umożliwiająca prowadzenia na terenie PRL działalności gospodarczej przez zagraniczne podmioty gospodarcze.

Udział głównych partnerów Polski w jej globalnych obrotach handlowych w latach 1970-1977 wskazywał na rosnącą pozycję Austrii w gronie państw wysoko rozwiniętych. W roku 1970 eksport do Austrii wynosił 1,4\% całości polskiego wywozu, co plasowało to państwo na siódmym miejscu w gronie państw zachodnich. Dla porównania w tym roku udział eksportu wyniósł dla najsilniejszych partnerów - RFN -

87 P. Franaszek, Die Handelsbeziehungen zwischen..., s. 190. 
$5,5 \%$, Włochy $-3,8 \%$, USA - 2,6\%. W tym samym okresie import z Austrii wyniósł $2,5 \%$, a u schyłku dekady $3,6 \%$ ogółu obrotów handlowych, co dawało piąte miejsce w gronie państw rozwiniętych. Był to wynik podobny do importu towarów ze Stanów Zjednoczonych i Francji ${ }^{88}$.

Przyspieszenie inwestycyjne, jakie zapowiadano w latach siedemdziesiątych, miało wynikać nie z rekonstrukcji i modernizacji istniejących zakładów produkcyjnych, lecz budowy nowych. Kredyty udzielane Polsce były przedmiotem żmudnych negocjacji i w miarę postępującego kryzysu były jedynym gwarantem utrzymania dotychczasowych wpływów. Polskie władze nie martwiły się o warunki ich podpisywania $\mathrm{w}$ istniejącej sytuacji, gdyż jak twierdziły - instytucje finansowe poszukiwały chętnych na pieniądze zalegające $\mathrm{w}$ bankach ${ }^{89}$. Błędy decyzyjne wynikały również z rozliczania bilansów płatniczych w cenach bieżących. W roku 1975 zostały przekroczone wskaźniki uznawane powszechnie za dopuszczalną granicę zadłużenia. Wynikało to z wielu zaniedban, braku wiedzy i możliwości, nieuczciwości i braku planowania ${ }^{90}$. Trudno dziś ustalić skalę nadużyć ze względu na liczne działania cenzury w obszarze, który dotyczył wymiany handlowej zarówno z krajami zachodnimi, jak i RWPG. Poczynając od roku 1980 Polska miała spłacać Austrii od 1,3 do 5,2 mld dolarów, tak aby całość zadłużenia spłacić do 1990 roku. Prawie połowa całej kwoty miała zostać uiszczona w latach 1982-1985 - łącznie 20 mld dolarów, co w panujących wówczas warunkach było niemożliwe ${ }^{91}$.

Aby sprostać wymaganiom kredytowym zaciągano nowe pożyczki, często pod presją inwestorów, którzy pod groźbą wycofania się z umów domagali się zaciągania kolejnych zobowiązań ${ }^{92}$. Następstwem wielkiej fali inwestycyjnej z pierwszej połowy dekady były ograniczenia importowe $\mathrm{w}$ drugiej pięciolatce ${ }^{93}$. Ograniczenia te przeprowadzono po 1976 roku kosztem jakości produkowanych na eksport produktów i wydłużenia procesu inwestycyjnego. Rozdział środków na modernizację konsekwentnie pomijał gałęzie produkujące i świadczące usługi dla ludności (handel, rolnictwo, gospodarka komunalna i mieszkaniowa), co w efekcie wywołało niezadowolenie społeczne.

Na początku lat osiemdziesiątych Austria miała jednak nadal bardzo istotny problem z niezrealizowanymi polskimi płatnościami wynikającymi z zobowiązań paryskich i będącymi wynikiem umowy bilateralnej ${ }^{94}$. Chodziło o spłatę $400 \mathrm{mln}$ szylingów z 1981 roku. Zdaniem Austrii Wiedeń stworzył warunki międzynarodowe pozwalające na spła-

\footnotetext{
88 A. Czepurko, J. Giezgała, Handel zagraniczny Polski w latach siedemdziesiatych. Wyniki, zadania i perspektywy, Państwowe Wydawnictwo Ekonomiczne, Warszawa 1978, s. 16.

89 S. Długosz, Jak zadtużyłem PRL, Polska Agencja Ekologiczna, Warszawa 1995, s. 43. W Polsce przyjęto błędne założenie, że inflacja w krajach zachodnich doprowadziła do obniżenia kosztów kredytów zagranicznych.

90 L. Jasiński, Blizej centrum czy na peryferiach..., s. 274.

91 A. Kisztelińska-Węgrzyńska, Bruno Kreisky. Polityka zagraniczna..., s. 261.

92 W. Rydygier, Pułapka zadtużenia, w: A. Müller (red.), U źródet polskiego kryzysu. Społeczno-ekonomiczne uwarunkowania rozwoju gospodarczego Polski w latach siedemdziesiatych, Państwowe Wydawnictwo Ekonomiczne, Warszawa 1985, s. 239.
}

93 A. Ząbkowicz, Koncepcja zagranicznej..., s. 35.

94 Klub Paryski, jako nieformalna grupa wysokich urzędników najbogatszych państw, zajmujaca się finansami w kontekście restrukturyzacji i umarzania długów krajowych, podjął temat polskiego 
tę tej części długu. Tymczasem Polska wydatkowała te środki na pokrycie zobowiązań w innych państwach ${ }^{95}$. Projekt pomocy dla Polski przygotowany przez austriacki rząd nie doczekał się realizacji $\mathrm{w}$ przedstawionej postaci, ponieważ nie znalazł poparcia wśród innych państw europejskich ${ }^{96}$.

Wstrzymywanie się w latach osiemdziesiątych od zaciągania kredytów i próby wykorzystania nadwyżki handlowej, która pokryłaby obsługę długu, były skazane na niepowodzenie ze względu na wielkość sumy. Ograniczenie importu i niezbędne zwiększenie wpływów eksportowych spowodowałoby natomiast konieczność zamknięcia wielu zakładów przemysłowych, pracujących na importowanych surowcach i materiałach oraz ogołociłoby do reszty rynek krajowy z towarów, a więc doprowadziłoby do obniżenia stopy życiowej, ze wszystkimi tego politycznymi konsekwencjami. Pozostało więc tylko starać się o uzyskanie za wszelką cenę odpowiednich kredytów finansowy $\mathrm{ch}^{97}$. Jednocześnie polskie władze podejmowały wysiłki w celu przyciągnięcia do Polski kapitału zagranicznego. Postawą prawną były nowe regulacje prawne z lipca 1982 roku o zagranicznych przedsiębiorstwach drobnej wytwórczości. Umożliwiały one udzielanie zezwoleń zagranicznym podmiotom gospodarczym na prowadzenie działalności. Określały opodatkowanie i kredytowanie takiej działalności, a także precyzowały warunki przekazywania zysków za granicę. Ówczesny napływ obcego kapitału okazał się niewielki, choć liczba przedsiębiorstw zagranicznych działających na terenie Polski wzrastała $^{98}$.

W dobie kryzysu, czyli po 1981 roku, władze austriackie aktywnie uczestniczyły w tworzeniu planu pomocy gospodarczej dla Polski. Działo się to przy udziale przedstawicieli firm inwestujących, np. Voest Alpine, mających dobre doświadczenia we współpracy z polskimi władzami. Rozmowom na temat przyszłych inwestycji w krajach rozwijających się czy tranzytu rudy przez porty w Szczecinie i Świnoujściu towarzyszył dialog na temat zwalniania internowanych i łagodzenia skutków stanu wojennego. Komponent społeczny miał duże znaczenie podczas negocjacji na temat umów dwustronnych czy wymiany handlowej. Władze austriackie zakładały, że działania, jakie podejmują na terenie Polski, miały przyczynić się do emancypacji politycznej państw wschodnich, przebiegającej w sposób ewolucyjny. Nacisk na umowy dotyczące wymiany naukowej, transferu technologii i współpracy pomiędzy ośrodkami badawczymi pozostał jedynie w sferze deklaracji. Jednocześnie udział Polski w kształtowaniu nowego modelu gospodarczego na tym obszarze miał eliminować bariery w stosunkach pomiędzy Wschodem i Zachodem. Austria agitowała szczególnie za kooperacją Polski z państwami skandynawskimi. Związki II Republiki z państwami neutralnymi sięgały

zadłużenia po raz pierwszy w 1980 roku. Porozumienia paryskie z 1981 roku przewidywały refinansowanie polskich zobowiązań przypadających na 1981 rok do kwoty 2,2 mld dolarów.

95 AMSZ D. IV Austria, z. 45/86, w. 4, Pilna notatka z 20 kwietnia 1983 roku, s. 6.

96 D. Stiefl, Österreich und die planwirtschaftlichen Länder, w: G. Enderle-Burcel (red.), Zarte Bande: Österreich und die europäischen planwirtschaftlichen Länder. Delicate relationship, WUV-Universitätsverlag, Wien 2006, s. 19-24.

97 A. Ząbkowicz, Koncepcja zagranicznej polityki kredytowej w Polsce w latach 1971-1980, Wydawnictwo Ossolineum, Wrocław 1992, s. 89.

98 T. Małecka, Przedsiębiorstwa zagraniczne w Polsce, „Handel Zagraniczny” 1989, nr 12, s. 5-8. 
czasu II wojny światowej. Jeszcze w trakcie trwania okupacji alianckiej Wiedeń podpisał pierwsze intratne umowy gospodarcze ze Szwecją.

W czerwcu 1986 roku Polska ponownie przystąpiła do Międzynarodowego Funduszu Walutowego i Banku Światowego, których była członkiem założycielem w 1944 roku i z których pod wpływem ZSRR wystąpiła w 1950 roku. Dawało to możliwość zaciągania kredytów dla zrównoważenia bilansu płatniczego. Rozwinięto również inwestycje za pomocą pożyczek z Banku Światowego. Inwestycje w przetwórstwo i sektor maszynowy przynosiły zyski nawet $\mathrm{w}$ najtrudniejszym okresie drugiej dekady lat osiemdziesiątych. Struktura eksportu według grup towarów wskazuje na dominację wyrobów przemysłu od 74 do $80 \%$ w 1988 roku, natomiast paliwa i energia stanowiły od 15 do $10 \%$. Pozostałe towary wyniosły łącznie niecałe $10 \%{ }^{99}$. Jednocześnie wzmacniany przez stronę austriacką przemysł elektromaszynowy i chemiczny generował w tym czasie największe zyski w eksporcie, przewyższając wielokrotnie pozostałe gałęzie ${ }^{100}$. $\mathrm{Na}$ progu transformacji wśród największych inwestorów zagranicznych w Polsce pozostawały firmy: niemieckie, holenderskie i amerykańskie, pozostałe 32 kraje, w tym również Austria, posiadały 51\% udziału w ogólnej liczbie inwestorów. Dane przekazane za pośrednictwem spółek do Narodowego Banku Polskiego (NBP) wskazują na działalność 747 inwestorów z Austrii, co dało 5\% ogólnego udziału w kapitale zagranicznym na terenie Polski. Dochody, jakie Austria uzyskała z tytułu kapitału zainwestowanego w Polsce, osiągnęły $14 \mathrm{mln}$ dolarów i były porównywalne do brytyjskich ${ }^{101}$.

Wspólne działania na rzecz wprowadzenia regulacji prawnych przynosiły długofalowe efekty ekonomiczne. W kwietniu 1986 roku i w grudniu 1988 roku wprowadzono ustawowe podstawy działalności gospodarczej z udziałem podmiotów zagranicznych, czyli joint ventures. Ta druga regulacja była szczególnie korzystna dla inwestorów zagranicznych, którzy mogli posiadać nawet 100\% kapitału spółek. Ustawa zezwalała na transfer zysku dewizowego za granicę i zwalniała powstające przedsiębiorstwa od podatku dochodowego na trzy lata ${ }^{102}$.

Biorąc pod uwagę potencjalne skutki napływu austriackich inwestycji bezpośrednich do Polski ze względu na przekształcanie określonych obszarów (zasoby, przedsiębiorczość, efektywność i stosunki polityczno-ekonomiczne), to największe korzyści można osiągać w rozwoju zasobów, najmniejsze zaś w poprawie efektywności. Zasadniczym celem austriackiej polityki inwestycyjnej w Polsce było stworzenie stosunków multilateralnych opartych na ułatwieniach płatniczych i celnych, a co za tym idzie - stworzenia grup wsparcia, wspólnych instytucji tych państw ${ }^{103}$. W tym zakresie Austria współpracowała z innymi krajami zachodnimi (Francją, RFN, Włochami i USA).

99 L. Jasiński, Bliżej centrum czy na peryferiach..., s. 289.

100 E.M. Jagiełło, Zmiany w sile nabywczej eksportu Polski w latach 1980-1988, „Handel Zagraniczny" 1989, nr 3.

101 Narodowy Bank Polski, Serwis Informacyjny, https://www.nbp.pl/publikacje/zib/zib2003.pdf (dostęp: 15 września 2020).

102 L. Jasiński, Bliżej centrum czy na peryferiach..., s. 297.

103 J. Skodlarski, Zarys historii gospodarczej Polski, Państwowe Wydawnictwo Ekonomiczne Warszawa 2005, s. 448-453, 475-485; J. Kaliński, Z. Landau, Gospodarka Polski w XX wieku, Polskie Wydawnictwo Ekonomiczne, Warszawa 1998, s. 281-283. 
Inwestycje austriackie przyniosły wzrost importu z Austrii o 800\% (1970-1979). Wartość eksportu rosła powoli, lecz systematycznie do $400 \%$ w porównaniu z 1970 rokiem i dotyczyła głównie surowców energetycznych ${ }^{104}$. Zrealizowano ograniczoną część przyjętych planów. Niepowodzeniem zakończyła się koncepcja budowy w Polsce przy udziale kapitału austriackiego elektrowni atomowej, arterii łączącej kilka ważnych rzek czy kopalni miedzi ${ }^{105}$. Plany te przedstawione bezpośrednio przez kanclerza Bruno Kreisky’ego świadczyły o chęci wpisania Polski do grona długofalowych partnerów gospodarczych i pozytywnej oceny naszego państwa na tle innych krajów Europy Środkowo-Wschodniej. Polskie władze związane ściśle instrukcjami sowieckimi skupiały się na modernizacji przemysłu zbrojeniowego.

Ważnym elementem współpracy gospodarczej były kontrakty zawierane przez przedsiębiorstwa i koncerny obydwu państw. Skutkiem działań tychże transakcji był prawie 10\% udział całości obrotów w poszczególnych sektorach. Największy kontrakt kooperacyjny w latach siedemdziesiątych zawarto pomiędzy austriackim Steyr-Dimler-Puch AG a PMZ „Pol-Mot” na globalną kwotę 4,5 mld szylingów. Wśród innych ważnych przedsięwzięć wymienić należy: budowę i montaż górniczych kombajnów pokładowych; współpracę na rynkach trzecich przy budowie kompletnych obiektów dla przemysłu chemicznego, spożywczego, drzewnego i cukrowniczego; współtworzenie, projektowanie i sprzedaż obiektów przemysłu hutniczego (Centrozap-Voest Alpine).

Bilans zaangażowania austriackich firm na obszarze Europy Środkowej w 1990 roku dotyczył w głównej mierze inwestycji w przetwórstwo i usługi finansowe ${ }^{106}$. W Polsce duża liczba realizowanych projektów skupiała się na rozwoju przetwórstwa, sektora usług, handlu, komunikacji i przemysłu maszynowego. Szacuje się, że pod koniec lat osiemdziesiątych trzy czwarte kapitału zagranicznego lokowane było w szeroko rozumianych usługach, przy czym handel odgrywał dominującą rolę. Wynikało to z możliwości szybkiego wycofania zainwestowanego kapitału w razie pogorszenia sytuacji. Większość kapitału inwestycyjnego została rozdysponowana w przemyśle maszynowym, chemicznym i spożywczym, co było widocznym i konsekwentnym działaniem podmiotów europejskich w starciu z konkurencyjnymi branżami amerykańskimi ${ }^{107}$. Projekty amerykańskie, choć było ich znacznie mniej, miały większą wartość kapitału i zakładały współpracę wielostronną. Odmienność rynku polskiego przejawiała się w tym, że dwie trzecie kapitału płynącego z inwestycji bezpośrednich przeznaczano na przetwórstwo. Nie było wyraźnych trendów dotyczących branżowości. Choć atutem były tanie koszty i wykwalifikowani robotnicy, to wbrew prognozom przemysł lekki czy elektroniczny nie dominował ani w Polsce, ani w pozostałych krajach sąsiednich. Polskie władze miały świadomość rosnących dysproporcji. Choć uznano poprawę w sferze jakości i specjalizacji produkcji, podnoszenia efektywności i wzrostu eksportu za niedostateczne, to jednocześnie zaplanowano, że po zrównoważeniu bilansu artykułami

\footnotetext{
104 Ibidem, s. 192.

105 Chronik der Grünen Alternative. Die Grüne Alternative als Parlamentspartei (1986-2015), Böhlau-Verlag, Wien 2015, s. 32.

106 S. Lane, The Pattern of Foreign Direct Investment and Joint Ventures in Hungary, „Communist Economies and Economic Transformation" 1994, t. 6, nr 3, s. 341-365.

107 K.E. Meyer, Foreign Direct Investment..., s. 316.
} 
rolnymi Polska powróci na rynki światowe jako uznany eksporter artykułów rolno-spożywczych. Jak twierdzi Anna Ząbkowicz te dwie idee można uznać za klęskę polityki modernizacji gospodarki i elektromaszynowej specjalizacji w eksporcie ${ }^{108}$.

Wspólne działania podnoszące efektywność polskiej gospodarki i generujące przedsiębiorczość wiązały się z powoływaniem mieszanych grup roboczych uzgadniających zarówno treści przygotowywanych aktów prawnych, jak i monitorujących realizację podpisanych umów. Wypracowanie wspólnego stanowiska w kwestii działań na rynkach trzecich to chociażby powołanie dziewięciu zespołów inwestycji głównie na obszarze Bliskiego Wschodu i Azji. Obszar ten miał stać się bazą dla wspólnych przedsięwzięć i mocnym zapleczem politycznym dla rozwoju ruchu socjaldemokratycznego. Wśród pomysłów odrzuconych ze względu na koszty znalazły się m.in. uruchomienie produkcji koksu naftowego w Polsce, utworzenie polsko-austriackiej spółki w przemyśle motoryzacyjnym, budowa rurociągu do przesyłania węgla czy dostarczanie energii elektrycznej do Austrii ponad już uzgodnione wartości.

W celu koordynacji prac nad rozbudową stosunków gospodarczych polskie władze powołały na początku lat siedemdziesiątych XX wieku pięć zespołów roboczych: a) do spraw paliw i energetyki, b) do spraw hutnictwa, przemysłu maszynowego i chemii, c) do spraw przemysłu rolno-spożywczego, d) do spraw budownictwa, e) do spraw polityki zagranicznej ${ }^{109}$. W efekcie prac grup roboczych podpisano, w ciągu roku od pierwszej wizyty kanclerza w Polsce (1973), siedemnaście umów pomiędzy firmami polskimi i austriackimi. Wśród najważniejszych inwestycji w Polsce wymienić należy choćby budowę kombinatu górniczo-hutniczego Polimex-Cekop, rozbudowę i modernizację rafinerii płockiej, budowę zakładów azotowych i budowę zakładów maszyn i systemów kontroli Elektrim ${ }^{110}$. W polskim MSZ z uwagą analizowano koncepcję współpracy poza Europą. Głównym celem tego programu była współpraca gospodarcza i finansowa polegająca na budowie infrastruktury i zakładająca poprawę życia w krajach Ameryki Południowej, Azji i Afryki. Obszar ten miał stać się bazą dla wspólnych przedsięwzięć i mocnym zapleczem politycznym dla ruchu socjaldemokratycznego ${ }^{111}$. Rozszerzając współpracę na rynkach trzecich, odnoszono pewne sukcesy. Wybudowano rafinerię ropy w Kongo i Mauretanii, fabrykę celulozy w Kamerunie, a także zakłady metalurgiczne w Libii i Wenezueli ${ }^{112}$.

Dla Polski BIZ były związane z oczekiwaniami głównie w zakresie uzupełnienia niedoborów kapitałowych wynikających $\mathrm{z}$ niedostatecznych oszczędności, technologicznego unowocześnienia gospodarki i upowszechnienia nowoczesnych metod zarządzania, zmniejszenia bezrobocia przez generowanie popytu na rynku pracy i intensyfikacji gospodarczej regionów słabiej rozwiniętych ${ }^{113}$. Wśród korzyści związanych

\footnotetext{
108 A. Ząbkowicz, Koncepcja zagranicznej..., s. 79.

109 AMSZ, D.IV Austria, z.44/77, w. 7. Austria-1973, Pilna notatka z 9 lipca 1973.

110 StBKA, Offizieller Besuch des BK in Polen, 25.-26. Juni 1973, Länderbox Polen Box 5.

111 AMSZ, D.IV Austria, z. 43/84, w. 5, Aktualne elementy austriackiej polityki zagranicznej, maj 1980 roku, s. 8.

112 E. Bryl-Warewicz, Stosunki polsko-austriackie..., s. 267.

113 T. Sporek, Atrakcyjność inwestycyjna Polski w latach 1990-2016-trendy, struktura i perspektywy, „Studia Europejskie” 2017, nr 4, s. 97.
} 
z rozwojem austriackich inwestycji wymienić należy: zniesienie systemu kontyngentowania i zliberalizowanie wzajemnej wymiany towarowej. Określono warunki swobodnego przepływu towarów i finansów. Usprawniono wymianę towarów i systematycznie uzupełniano listy dóbr wymiany towarowej. Systematycznie uzupełniano przepisy regulujące działalność i wsparcie dla rozwoju małych i średnich przedsiębiorstw. Dzięki odpowiednim regulacjom promowano wzrost udziału mniejszych podmiotów gospodarczych w obrotach handlowych pomiędzy Polską i Austrią ${ }^{114}$.

\section{Wnioski}

Wpływ austriackich inwestycji na postawy władz polskich w zakresie aktywności na rzecz rozwoju: zasobów, przedsiębiorczości, efektywności i stosunków społecznych nie był jednoznaczny. Każdy z tych komponentów należy ocenić odrębnie. W światowej gospodarce inwestycje zagraniczne są jedną z głównych sił napędowych rozwoju gospodarek. Choć wpływ inwestycji austriackich był widoczny, nie przyczyniły się one do poprawy sytuacji w dhuższej perspektywie, gdyż napotkały niedoinwestowaną gospodarkę. Dysproporcje w rozwoju poszczególnych gałęzi przemysłu czy brak możliwości eksportu towarów atrakcyjnych, za które Polska mogłaby otrzymywać dewizy potrzebne do spłaty długów, przyspieszyły kryzys lat osiemdziesiątych.

Analizując polskie inicjatywy dyplomatyczne i porozumienia traktatowe w okresie powojennym należy stwierdzić, że działania te były częścią większego planu realizowanego wobec państw zachodnich. Systematycznie od połowy lat sześćdziesiątych $\mathrm{XX}$ wieku państwo polskie liberalizowało swoje praktyki w celu przyciągania inwestycji, promowało korzystne warunki dla potencjalnych inwestorów, a zdobywanie nowych kontaktów wiązało się z długofalowymi celami rozwojowymi Polski. W efekcie stworzono infrastrukturę instytucji zajmujących się tworzeniem warunków do pozyskiwania zagranicznych inwestycji i ich selekcji. Należy podkreślić, że wraz z poszerzaniem się kręgu państw zachodnich zainteresowanych współpracą z polskimi władzami, stosunek decydentów w Warszawie do propozycji płynących z zagranicy zmienił się. Podejmując decyzję na temat udziału w inwestycjach przy udziale państw trzecich, szacowano także koszty polityczne i ewentualne straty w wyniku niepowodzeń. Mobilizacja zasobów ludzkich, kapitałowych, surowców i implementacja nowych rozwiązań technicznych poprawiła warunki społeczno-ekonomiczne. U schyłku lat osiemdziesiątych dominowały jednak przedsiębiorstwa drobnej wytwórczości. Nie zniesiono obszarów potencjalnych konfliktów na drodze do uregulowania sytuacji prawnej. Utrzymano wymogi dotyczące uzyskiwania dodatkowych zezwoleń w przypadku dziedzin wrażliwych czy przyznawania ulg podatkowych.

Z czasem brak reform w Polsce zniechęcił austriackich partnerów do tego stopnia, że zaprzestali inicjowania programów pomocowych czy wsparcia w postaci wspól-

\footnotetext{
114 Wśród regulacji ważne były dwa traktaty podpisane w 1980 roku: Umowa o rozszerzeniu wspótpracy gospodarczej, przemysłowej i technicznej małych i średnich przedsiębiorstw, między Rzadem Polskiej Rzeczypospolitej Ludowej a Austriackim Rządem Związowym z 21 kwietnia 1980 roku i Protokót w sprawie pogłębiania wspótpracy przemysłowej na rynkach krajów trzecich między przedsiębiorstwami polskimi i austriackimi z 20 lutego 1980 roku.
} 
nych inwestycji na rynkach trzecich. Ograniczono się do zabezpieczenia własnych najważniejszych interesów z obawy o dotkliwe straty wynikające z polskiego zadłużenia i niezadowolenia społecznego w Austrii zalewanej przez emigrantów z Polski. Bilans napływu inwestycji zagranicznych do Polski na przełomie 1989/1990 roku wyniósł 200 mld dolarów i przez kolejne cztery lata utrzymywał się na stałym, niskim poziomie $^{115}$. Państwa zachodnie reprezentujące największych inwestorów zagranicznych w Europie Środkowo-Wschodniej preferowały w tym czasie inne lokalizacje, co jest wyraźnie widoczne podczas analizy wyników wymiany gospodarczej w pierwszych latach transformacji ustrojowej.

Cele polityczne, jakie przy okazji współpracy gospodarczej realizowano - integracja państw wschodnich w regionie - nie spełniły oczekiwań. Austriacy poprzez współpracę z Polską dążyli do umocnienia pozycji gospodarczej i politycznej sąsiednich państw wschodnich, ale czynili to głównie w trosce o zabezpieczenie wschodnich granic. Priorytety $\mathrm{w}$ rozwoju republiki zakładały, aby państwo to działając w podwójnym peryferyjnym położeniu (mocarstwa i państwa komunistyczne) kierowało się racją stanu i niezależnością. W tej części kontynentu nie było to proste zadanie ze względu na granice z państwami o różnych systemach politycznych. Polityka dobrego sąsiedztwa oznaczała generalnie gotowość do porozumienia. Austria konsekwentnie popierała dążenia państw wschodnich do rozwoju w ramach istniejących struktur politycznych i ekonomicznych. Wzmacnianie naddunajskiej stolicy w otoczeniu międzynarodowym przyniosło w latach siedemdziesiątych wymierne korzyści materialne i rozbudowę Wiednia - siedziby wielu światowych instytucji. Tymczasem państwa wschodnie nie były w stanie wypracować przed 1989 rokiem skutecznej współpracy w ramach regionu. Zabiegały jedynie o wizyty państwowe, uregulowanie relacji dwustronnych i aprobatę państwa neutralnego - zachodniego. Kontakty pomiędzy Warszawą a pozostałymi pięcioma stolicami wschodnimi miały charakter fasadowy i były nacechowane nieufnością. Wśród zagrożeń dla gospodarki polskiej płynących z tak rozwijanej współpracy wymienić należy: pogorszenie bilansu płatniczego z powodu odpływu kapitału inwestowanego w Polsce, łączenie nowych projektów z koniecznością zaciągania kredytów inwestycyjnych na niekorzystnych warunkach, nacisk na wybrane, tradycyjne sektory gospodarcze i pozbawienie lokalnych firm możliwości wytworzenia własnych specyficznych przewag własnościowych.

Austria dała jednak podstawy do późniejszej współpracy tego obszaru ze strukturami WE i przyspieszyła proces transformacji. Inwestycje poczynione przed 1989 rokiem stały się elementem budowy potencjału ekonomicznego ważnego podczas prac nad przystąpieniem Polski do struktur UE. Kraje, w których odnotowano dużą liczbę inwestycji bezpośrednich z Austrii i Niemiec realizowanych przed 1989 rokiem, stały się liderami w procesie akcesji do struktur europejskich. Natomiast kwestia integracji, jaką zakładał Wiedeń w ramach regionu, podjęta została w ramach działań Grupy Wyszehradzkiej, lecz już bez wyraźnego udziału Wiednia. W latach dziewięćdziesiątych

115 UNCTAD, Foreign Direct Investment: Inward and outward flows and stock, annual, 1970-2015, http://unctadstat.unctad.org/wds/TableViewer/tableView.aspx?ReportId=96740 (dostęp: 12 września 2020). 
II Republika przeniosła ciężar zainteresowań gospodarczych na obszar Bałkanów, Kaukazu i Bliskiego Wschodu ${ }^{116}$.

\begin{abstract}
Austrian Investments in Poland before 1989

Austrian investments in Poland developed with varying intensity throughout the 20th century. The Second Austrian Republic exerted a visible influence on the eastern area in terms of entrepreneurship, the intensity of this process, the degree of generated changes and the effects in relation to Poland require clarification. Poland was treated by post-war Austria as an initiator of changes in the region and a partner in the exchange of goods and raw materials. The aim of the article is to assess the impact of Austrian economic stimuli, mainly direct investments, on the political situation in Poland. Their effectiveness is estimated on the basis of specific initiatives undertaken, not only for the sake of the national interest of the republic, but also responsibility for economic and political support for the area of Central and Eastern Europe. An important question remains how the Polish government reacted to the offers made by the Austrian authorities. The adopted hypothesis concerns integration in the region. The Austrians, through cooperation with Poland, sought to strengthen the economic and political position of the neighboring eastern countries.
\end{abstract}

Keywords: Modern Austria, FDI, Austrian-Polish relations, investment policy, Central Europe.

116 A. Kisztelińska-Węgrzyńska, Austriacka polityka zagraniczna w XXI wieku. Kontynuacja i zmiana, „Przegląd Zachodni” 2016, nr 4, s. 281-299. 